\title{
SYSTEM KONTROLI I EGZEKWOWANIA PRAWA POMOCY PUBLICZNEJ W UNII EUROPEJSKIEJ - KOMPETENCJE KOMISJI EUROPEJSKIEJ I JEJ WSPÓŁPRACA Z SĄDAMI PAŃSTW CZŁONKOWSKICH W LATACH 2000-2010
}

\begin{abstract}
WSTĘP
Zagwarantowanie istnienia niezakłóconej konkurencji ${ }^{1}$ między przedsiębiorstwami w państwach członkowskich nie byłoby możliwe bez stworzenia kompletnego katalogu przepisów odnoszących się do kontroli udzielania pomocy publicznej, zawartych w art. 107-109 Traktatu o funkcjonowaniu Unii Europejskiej² (dalej: TFUE). Przepisy te stoją na straży ujednoliconych w ramach wspólnego rynku reguł konkurencji oraz ściśle definiują warunki jakiejkolwiek ingerencji państw członkowskich na korzyść określonych przedsiębiorstw³ ${ }^{3}$ W sytuacji, w której podjęta interwencja spełnia przesłanki zawarte w art. 107 ust. 1 TFUE, domniemywa się występowanie działań naruszających konkurencję, prowadzących nie-
\end{abstract}

1 Zob. W. Bokajło, A. Pacześniak (red.), Równośc w Unii Europejskiej-teoria i praktyka, Wrocław 2008; Z. Brodecki (red.), Konkurencja, Lexis Nexis, Warszawa 2004; T. Korbutowicz, Polityka konkurencji Wspólnoty Europejskiej i Unii Europejskiej w latach 1962-1997, Oficyna Ekonomiczna, Kraków 2004; B. Majewska-Jurczyk, Dominacja w polityce konkurencji Unii Europejskiej, Wrocław 1998; T. Przybyciński, Konkurencja i tad rynkowy - przyczynek do teorii i polityki konkurencji, Warszawa 2005.

2 Traktat o funkcjonowaniu Unii Europejskiej z 9.05.2008 r., Dz. Urz. UE C 115/2008.

3 M. Kąkol, Pomoc państwowa w polityce konkurencji w Unii Europejskiej, Lublin 2007, s. 17; A. Nykiel-Mateo, Pomoc państwa a ogólne środki interwencji w europejskim prawie wspólnotowym, Oficyna Wolters Kluwer, Warszawa 2009, s. 11. 
uchronnie do dyskryminacji tych podmiotów, które nie otrzymały wsparcia ze źródeł państwowych ${ }^{4}$.

Udzielanie pomocy publicznej może prowadzić do spadku dobrobytu społecznego, przekładając się na nieefektywną alokację zasobów ${ }^{5}$. $Z$ tego powodu niewydajne przedsiębiorstwa powinny być wyłączone $z$ możliwości ubiegania się o wsparcie na pokrycie własnych strat, o ile nie podejmą wszelkich środków zmierzających do podniesienia ich konkurencyjności. $Z$ drugiej strony pomoc publiczna może stać się skutecznym narzędziem kompensującym rozmaite zawodności mechanizmu rynkowego ${ }^{6}$. Za udzielaniem pomocy publicznej, jako leżącej w europejskim interesie, przemawia bowiem to, że ułatwia ona wprowadzanie nowoczesnych struktur przemysłowych, pobudzając tworzenie i utrzymywanie nowych miejsc pracy $^{7}$. Z tego powodu europejska polityka odnosząca się do stosowania pomocy publicznej powinna stanowić kompromis pomiędzy koniecznością i dopuszczalnością ingerencji państwa w rynek a ochroną niezakłóconej konkurencji ${ }^{8}$. W związku z powyższym w TFUE wprowadzono jedynie prewencyjny zakaz udzielania pomocy publicznej, oparty na art. 107 ust. 1, zastrzegając równocześnie w ust. 2-3 szerokie wyłączenia od tego zakazu, na podstawie których pomoc może zostać uznana za zgodną z zasadami wspólnego rynku. W ten sposób zagwarantowano efektywną kontrolę prawa pomocy publicznej, dokonywaną przez Komisję Europejską (dalej: Komisja) w postępowaniu przeprowadzanym na podstawie art. 108 TFUE. Do właściwości sądów państw członkowskich należy w tym kontekście ochrona kompetencji kontrolnych Komisji. Sądy krajowe w ramach postępowania, którego przedmiotem jest prawo pomocy publicznej, muszą ustalić, czy poddana badaniu ingerencja państwa mieści się w ramach art. 107 ust. 1 TFUE oraz jeśli zostanie to dowiedzione, orzekają, czy udzielenie pomocy publicznej było zgodne z prawem. Jeśli sąd krajowy stwierdzi, że przyznanie pomocy było pod względem formalnym niedopuszczalne, wyciąga $z$ tego tytułu konsekwencje, aby chronić monopol decyzyjny Komisji. Chronione są tym samym prawa i in-

\footnotetext{
S. Dudzik, Pomoc państwa dla przedsiębiorstw publicznych w prawie Wspólnoty Europejskiej. Między neutralnościq a zaangażowaniem, Kraków 2002, s. 42; M. Kośka, Co cesarskie cesarzowi. Zwrot pomocy państwa, [w:] B. Kurcz (red.), Pomoc państwa. Wybrane zagadnienia, C. H. Beck, Warszawa 2009, s. 329.

Z. Podlasiak, Pomoc publiczna a efektywność wykorzystania zasobórw, [w:] A. Fornalczyk (red.), Pomoc publiczna dla przedsiębiorstw w Unii Europejskiej i w Polsce, Warszawa 1998, s. 43.

6 K. Rutkiewicz, Pomoc publiczna w polityce konkurencji Unii Europejskiej a kryzys finansowy, [w:] G. Wrzeszcz-Kamińska (red.), Zawodność państwa. Zawodnośc rynku, Wrocław 2010, s. 182.

7 H. Ćwikliński (red.), Polityka gospodarcza, Gdańsk 2003, s. 145; M. Klamut, Polityka strukturalna, [w:] B. Winiarski (red.), Polityka gospodarcza, Warszawa 2006, s. 230.

8 A. Jankowska, M. Marek, Dopuszczalność pomocy publicznej. Uregulowania wspólnotowe i krajowe, C. H. Beck, Warszawa 2009, s. 20; I. Postuła, A. Werner, Pomoc publiczna, Warszawa 2006, s. 316.
} 
teresy konkurentów, którzy zostali poszkodowani z tytułu bezprawnie udzielonej pomocy 9 .

Celem niniejszego opracowania jest przedstawienie najważniejszych procedur i praktyki funkcjonowania systemu kontroli i egzekwowania prawa pomocy publicznej w Unii Europejskiej, ze szczególnym uwzględnieniem kompetencji Komisji oraz obowiązków państw członkowskich w tym zakresie.

\section{IDENTYFIKACJA POMOCY PUBLICZNEJ}

Zgodnie z art. 107 ust. 1 TFUE przyznawanie pomocy publicznej przez państwa członkowskie w jakiejkolwiek formie, która zakłóca lub grozi zakłóceniem konkurencji poprzez sprzyjanie określonym przedsiębiorstwom lub produkcji niektórych towarów, jest niezgodne ze wspólnym rynkiem, jeśli pomoc ta wywiera wpływ na warunki międzynarodowej wymiany handlowej. Europejski Trybunał Sprawiedliwości (dalej: ETS) jednoznacznie stwierdził, że Komisja oraz sądy państw członkowskich są uprawnione do interpretowania pojęcia pomocy publicznej ${ }^{10}$.

Pojęcie pomocy publicznej obejmuje m.in. dotacje i przywileje podatkowe dla przedsiębiorstw, jak również inwestycje ze środków publicznych dokonywane w sytuacjach, w których prywatny inwestor rynkowy odmówiłby przyznania wsparcia. Bez znaczenia pozostaje fakt, czy pomoc jest udzielana bezpośrednio przez państwo, organy publiczne lub prywatne, którym powierzono zadanie zarządzania pomocą. Jednakże, aby wsparcie świadczone na rzecz określonego przedsiębiorstwa mogło zostać uznane za pomoc publiczną, musi mieć ono charakter selektywny, prowadzący do uprzywilejowania określonego podmiotu względem tych, dla których taka forma wsparcia jest niedostępna ${ }^{11}$. Kryterium

9 D. Jalowietzki, K. Jaros, S. Klaue, H. P. Vennemann, Wspólnotowe reguty prawa konkurencji i ich znaczenie dla polskich sędziów, Urząd Ochrony Konkurencji i Konsumentów, Warszawa 2007, s. 46.

10 Sprawa 78/76, Steinike \& Weinlig v Federal Republic of Germany, Judgment of the Court of 22.03.1977, European Court reports, 1977, s. 595; sprawa C-39/94, Syndicat français de l'Express international (SFEI) and others v La Poste and others, Judgment of the Court of 11.07.1996, European Court reports, 1996, s. 3547; sprawa C-354/90, Fédération Nationale du Commerce Extérieur des Produits Alimentaires and Syndicat National des Négociants et Transformateurs de Saumon v French Republic, Judgment of the Court of 21.11.1991, European Court reports, 1991, s. 5505; sprawa C-368/04, Transalpine Ölleitung in Österreich GmbH, Planai-Hochwurzen-Bahnen GmbH, Gerlitzen-Kanzelbahn-Touristik GmbH \& Co KG v Finanzlandesdirektion für Tirol, Finanzlandesdirektion für Steiermark, Finanzlandesdirektion für Kärnten, Judgment of the Court of 5.10.2006, European Court reports, 2006, s. 9957.

${ }_{11} \mathrm{~W}$ tym przypadku pomoc powoduje zaburzenie równowagi pomiędzy niektórymi przedsiębiorstwami i ich konkurentami. Niemniej selektywność stanowi tę cechę pomocy publicznej, która 
to jest spełnione także w przypadku pomocy regionalnej i sektorowej, mających zastosowanie tylko do części terytorium państwa członkowskiego.

Kolejną istotną przesłanką niezgodności pomocy publicznej ze wspólnym rynkiem jest zakłócenie konkurencji, które może polegać na wzmocnieniu pozycji konkurencyjnej określonego przedsiębiorstwa oraz utrudnieniu funkcjonowania lub dostępu do rynku innych przedsiębiorstw w następstwie udzielenia pomocy ${ }^{12}$.

Pomoc publiczna może prowadzić do naruszenia wymiany handlowej między państwami członkowskimi, gdy na danym rynku występuje nadwyżka zdolności produkcyjnych, nawet jeśli udział beneficjenta pomocy w rynku wspólnotowym jest marginalny ${ }^{13}$. W tej sytuacji nieprzerwana obecność przedsiębiorstwa na rynku krajowym dzięki otrzymanej pomocy uniemożliwia konkurentom $\mathrm{z}$ innych państw członkowskich zwiększenie udziałów w tym rynku, a tym samym narusza międzynarodową wymianę handlową ${ }^{14}$.

W orzecznictwie sądów wspólnotowych ${ }^{15}$ oraz decyzjach Komisji często odnoszono się do kwestii, czy stosowane w państwach członkowskich instrumenty mogą stanowić pomoc publiczną. $Z$ tego względu Komisja wydała szczegółowe wskazówki m.in.w tak złożonych sprawach,jak: 1) stosowanie zasady prywatnego inwestora ${ }^{16}$ i testu prywatnego wierzyciela ${ }^{17}$; 2) uznawanie gwarancji państwowych $^{18}$, sprzedaży gruntów publicznych ${ }^{19}$ i prywatyzacji ${ }^{20}$ za pomoc publiczną;

odróżnia ją od tzw. środków ogólnych, mających zastosowanie do wszystkich firm bez względu na sektor gospodarki danego państwa, np. większość ogólnokrajowych środków fiskalnych.

12 T. Skoczny, Zakaz antykonkurencyjnej pomocy państwa, [w:] J. Barcz (red.), Prawo Unii Europejskiej, Warszawa 2004, s. 273.

13 Sprawa 730/79, Philip Morris Holland BV v Commission of the European Communities, Judgment of the Court of 17.09.1980, European Court reports, 1980, s. 2671.

14 Połączone sprawy C-278/92, C-279/92 i C-280/92, Kingdom of Spain v Commission of the European Communities, Judgment of the Court of 14.09.1994, European Court reports, 1994, s. 4103.

15 Sprawa C-280/00, Altmark Trans GmbH and Regierungspräsidium Magdeburg v Nahverkehrsgesellschaft Altmark GmbH, and Oberbundesanwalt beim Bundesverwaltungsgericht, Judgment of the Court of 24.07.2003, European Court reports, 2003, s. 7747.

16 Sprawa C-142/87, Kingdom of Belgium v Commission of the European Communities, Judgment of the Court of 21.03.1990, European Court reports, 1990, s. 959.

17 Sprawa C-342/96, Kingdom of Spain v Commission of the European Communities. Application of the statutory interest rate to agreements for the repayment of wages and the payment of debts in respect of social security contributions, Judgment of the Court of 29.04.1999, Official Journal C 204, 17.07.1999, s. 9.

18 Obwieszczenie Komisji w sprawie zastosowania art. 87 i 88 Traktatu WE do pomocy państwa w formie gwarancji, Dz. U. C 155 z 20.06.2008, s. 10.

19 Komunikat Komisji w sprawie elementów pomocy państwa w sprzedaży gruntów i budynków przez władze publiczne, Dz. U. C 209 z 10.07.1997, s. 3.

${ }_{20}$ Sprawa C-278/92, Kingdom of Spain v Commission of the European Communities, Judgment of the Court of 14.09.1994, European Court reports, 1994, s. 4103. 
3) ubezpieczanie kredytów eksportowych ${ }^{21}$; 4) opodatkowanie działalności gospodarczej ${ }^{22}$; 5) inwestowanie w kapital podwyższonego ryzyka ${ }^{23}$ oraz 6) udzielanie pomocy na prace badawczo-rozwojowe i innowacje ${ }^{24}$.

W przypadku jakichkolwiek wątpliwości dotyczących identyfikacji pomocy publicznej sądy państw członkowskich mogą zwracać się do Komisji o wydanie opinii. Działanie to związane jest z możliwością lub obowiązkiem zwracania się przez sądy krajowe do ETS-u o wydanie orzeczenia w trybie przewidzianym w art. 267 TFUE.

\section{NOWY SYSTEM KONTROLI PRAWA POMOCY PUBLICZNEJ W UNII EUROPEJSKIEJ}

Komisja posiada wyłączne kompetencje do oceny zgodności pomocy publicznej udzielanej przez państwa członkowskie z postanowieniami TFUE. W związku z tym kraje Wspólnoty są zobowiązane do zgłaszania (notyfikacji) Komisji wszelkich środków, zanim zostaną one przyznane ostatecznym beneficjentom ${ }^{25}$.

W Planie działań w zakresie pomocy publicznej ${ }^{26}$ przyjętym w 2005 r. Komisja ogłosiła, że przystąpi do walki z serią powszechnie znanych mankamentów w polityce udzielania pomocy publicznej, przekształcając ją w skuteczne narzędzie wspierania wzrostu gospodarczego i zatrudnienia. Plan zapoczątkował przegląd prawie wszystkich reguł i procedur odnoszących się do stosowania prawa pomocy publicznej. Sformułowano cztery zasady przewodnie, mające podtrzymywać reformę programową: 1) mniejsza i lepiej ukierunkowana pomoc publiczna; 2) precyzyjne podejście gospodarcze; 3) skuteczniejsze procedury, lepsze egzekwowanie, większa przewidywalność i zwiększona przejrzystość oraz 4) odpowiedzialność ponoszona wspólnie przez Komisję i państwa członkowskie.

21 Komunikat Komisji do państw członkowskich zmieniający zgodnie z art. 93 ust. 1 Traktatu WE komunikat dotyczący stosowania art. 92 i 93 Traktatu do krótkoterminowych ubezpieczeń kredytów eksportowych, Dz. U. C 325 z 22.12.2005, s. 22.

22 Obwieszczenie Komisji w sprawie stosowania reguł pomocy publicznej do środków związanych z bezpośrednim opodatkowaniem działalności gospodarczej, Dz. U. C 384 z 10.12.1998, s. 3.

23 Wytyczne wspólnotowe w sprawie pomocy państwa na wspieranie inwestycji kapitału podwyższonego ryzyka w małych i średnich przedsiębiorstwach, Dz. U. C 194 z 18.08.2006, s. 2.

24 Wspólnotowe zasady ramowe dotyczące pomocy państwa na działalność badawczą, rozwojową i innowacyjną, Dz. U. C 323 z 30.12.2006, s. 1.

25 Rozporządzenie Rady (WE) nr 659/1999 z 22.03.1999 r. ustanawiające szczegółowe zasady stosowania art. 93 TWE, Dz. Urz. UE L 83, 27.03.1999, s. 1-9.

26 State Aid Action Plan. Less and better targeted state aid: A roadmap for state aid reform 2005-2009, Commission of the European Communities, Brussels 07.06.2005, s. 1-18. 
W związku z uznaniem, że istnieje małe prawdopodobieństwo wywierania znacznego wpływu na warunki konkurencji we Wspólnocie przez całe programy lub konkretne kategorie pomocy, przyjęto system tzw. wyłączeń grupowych. Polega on na tym, że środki, które spełniają określone kryteria, mogą być udzielane bez konieczności ich uprzedniego zgłaszania Komisji27. Państwa członkowskie, których programy pomocowe zostały zgłoszone i zatwierdzone przez Komisję, mogą w przyszłości przyznawać pomoc indywidualną, nie będąc zobowiązane do dalszego informowania o tym fakcie Komisji. Niemniej konieczność zawiadomienia istnieje wciąż w przypadkach indywidualnych wniosków, obejmujących programy pomocy przekraczające określone wartościowo progi oraz w przypadkach udzielania pomocy poza programem, zwanej pomocą ad hoc.

W celu zapewnienia szybszej i skuteczniejszej realizacji procedur oraz ułatwienia procesu decyzyjnego Komisja dokonała w 2008 r. zasadniczych zmian w systemie kontroli prawa pomocy publicznej. Zadanie to zostało osiągnięte poprzez poddanie różnych środków pomocy publicznej takiemu poziomowi kontroli, który najlepiej odpowiada potencjalnemu wpływowi tych środków na konkurencję i warunki międzynarodowej wymiany handlowej. Nowy system jest oparty na trzech filarach obejmujących: wyłączenia grupowe, ocenę standardową i ocenę szczegółową.

Chociaż liczba środków podlegających wyłączeniom grupowym w ostatnich latach znacząco wzrosła, to w większości spraw, obejmujących indywidualne plany i programy pomocy, wciąż istnieje obowiązek ich notyfikacji przez Komisję, pociągający za sobą konieczność przeprowadzenia oceny standardowej tych środków. W 2009 r. ocena szczegółowa została przeprowadzona w 4 z 16 przypadków, które dotyczyły spraw związanych $z$ kapitałem podwyższonego ryzyka. W identyczny sposób poddano ocenie 9 z 30 przypadków pomocy na prace badawczo-rozwojowe i innowacje oraz 1 z 59 spraw odnoszących się do pomocy regionalnej ${ }^{28}$.

Aby zapewnić płynność w procesie zgłaszania zamiaru udzielania pomocy a priori zgodnej z regułami wspólnego rynku, w 2009 r. Komisja wprowadziła tzw. procedurę uproszczoną ${ }^{29}$, której celem jest zatwierdzanie pomocy publicznej $\mathrm{w}$ trybie przyspieszonym, obejmującym termin jednego miesiąca. Kolejnym udogodnieniem stał się Kodeks najlepszych praktyk odnoszących się do przebiegu

27 Rozporządzenie Komisji (WE) nr 800/2008 z 06.08.2008 uznające niektóre rodzaje pomocy za zgodne ze wspólnym rynkiem w zastosowaniu art. 87 i 88 Traktatu, Dz. Urz. L 214, 09.08.2008, s. 3.

28 State aid scoreboard. Report on state aid granted by the EU Member States. Autumn 2010 update, European Commission, Brussels 2010, s. 60.

${ }_{29}$ Zawiadomienie Komisji w sprawie uproszczonej procedury rozpatrywania niektórych rodzajów pomocy państwa, Dz. Urz. C 136, 16.06.2009, s. 3-12. 
postępowania w zakresie kontroli pomocy publicznej ${ }^{30}$. Został on oparty na wzajemnym zobowiązaniu Komisji i państw członkowskich do zwiększania sprawności i przewidywalności stosowanych procedur na każdym etapie postępowania w sprawach z zakresu pomocy publicznej.

Państwa członkowskie w coraz większym zakresie przyznają pomoc publiczną, która podlega przepisom o wyłączeniach grupowych na podstawie programów niewymagających dodatkowej notyfikacji Komisji. Nie uwzględniając środków przeznaczonych na walkę z kryzysem finansowym, w 2009 r. 964 sprawy (76\%) były związane $z$ nowo wprowadzaną pomocą publiczną, udzielaną $w$ ramach wyłączeń grupowych (rys. 1). Z drugiej strony w przypadku 226 programów (18\%) i 86 środków pomocy indywidualnej (6\%) konieczne było podjęcie decyzji przez Komisję. Oznacza to, że $94 \%$ środków pomocowych przeznaczonych dla sektora przemysłu i usług państwa członkowskie przyznały bez konieczności poddania ich ocenie na poziomie indywidualnych beneficjentów w postępowaniu przeprowadzanym przez Komisję ${ }^{31}$.

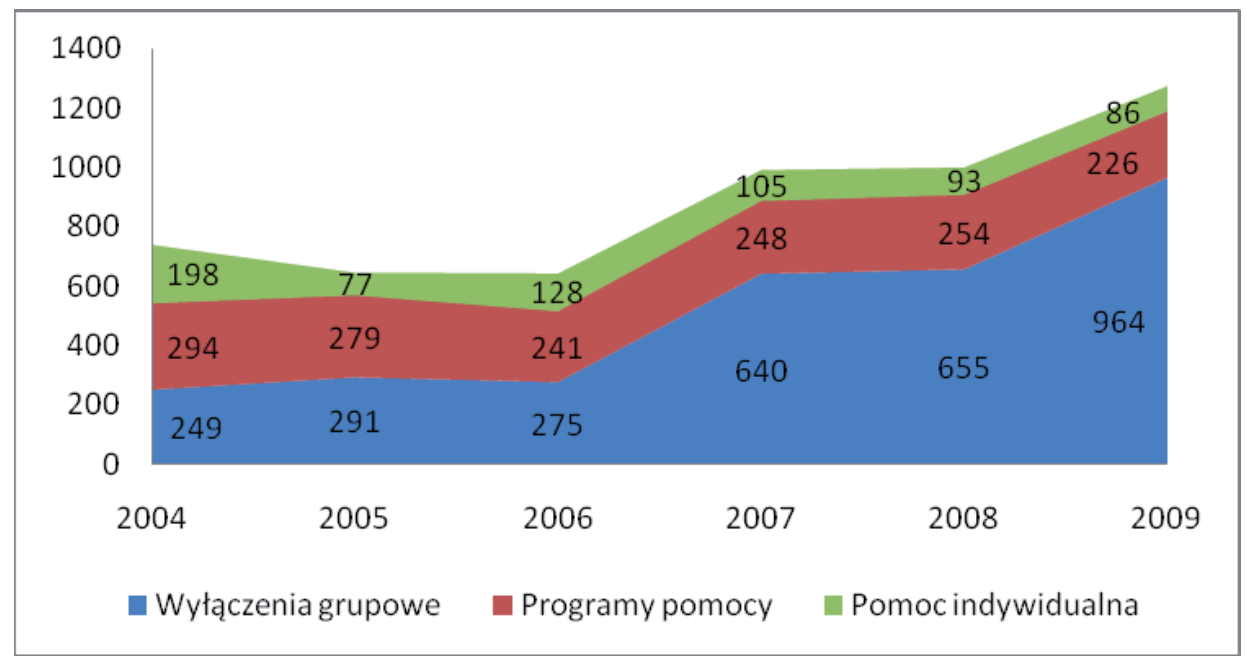

Rysunek 1. Kierunki zmian w liczbie środków pomocy publicznej w państwach UE-27 w zależności od jej typu

Źródło: opracowanie własne na podstawie danych z Dyrekcji Generalnej ds. Konkurencji.

W okresie 2004-2009 miał miejsce prawie 4-krotny wzrost liczby spraw odnoszących się do pomocy udzielanej w ramach wyłączeń grupowych, przy jednoczesnym spadku o ok. 50\% liczby spraw z zakresu pomocy indywidualnej, jak i zmniejszeniu się o 25\% liczby programów pomocy. Poza tym trendem, w ostat-

30 Komunikat Komisji, Kodeks najlepszych praktyk dotyczących przebiegu postępowania w zakresie kontroli państwa, OJ C 136, 16.06.2009, s. 13.

31 State aid scoreboard..., s. 62. 
nich latach obserwuje się również wzrost wartości i udziału pomocy w ramach wyłączeń grupowych w ogólnej wartości pomocy kierowanej do przemysłu i usług z 6,1 mld euro (13\%) w 2007 r. do 10,8 mld euro (19\%) w 2009 r. Wzrost ten można wyjaśnić systematycznie zwiększającą się wartością pomocy przeznaczanej na rozwój regionalny oraz w mniejszym stopniu pomocą dla małych i średnich przedsiębiorstw oraz na zatrudnienie i szkolenia pracowników.

Biorąc pod uwagę wartość pomocy publicznej w 2009 r., należy podkreślić, że pomoc udzielaną w ramach programów oszacowano na 40,4 mld euro, co stanowi 69\% całkowitej wartości wszystkich środków pomocowych. Na kolejnych miejscach znalazły się: pomoc w formie wyłączeń grupowych - 10,8 mld euro (19\%) oraz pomoc dla indywidualnych przedsiębiorstw $-6,9$ mld euro (12\%).

\section{EGZEKWOWANIE PRAWA POMOCY PUBLICZNEJ I WSPÓŁPRACA KOMISJI Z SĄDAMI KRAJOWYMI}

Komisja uważa,że egzekwowanie prawa pomocy publicznej przez narodowe sądy państw członkowskich odgrywa istotną rolę w całym wspólnotowym systemie kontroli pomocy publicznej. Narodowe sądy, z uwagi na ich lokalizację, posiadają kompetencje do skutecznej ochrony indywidualnych praw zakłócanych rozmaitymi naruszeniami reguł dopuszczalności pomocy publicznej oraz mogą zaoferować stronom trzecim szybkie i skuteczne środki odszkodowawcze ${ }^{32}$.

Pomimo ogólnego wzrostu liczby spraw z zakresu pomocy publicznej, w które uwikłane są narodowe sądy państw członkowskich, jedynie ograniczona liczba podejmowanych środków prawnych rzeczywiście zmierza do wykonalności wspólnotowego prawa dopuszczalności pomocy publicznej. $Z$ tego powodu Komisja dostrzega potrzebę jasnego doradzania narodowym sądom i potencjalnym stronom występującym z roszczeniami w różnych sprawach, które mogą powstać w kontekście postępowań na szczeblu narodowym. Celem doradztwa opartego na praktyce sądowej wspólnotowych organów jest w szczególności zajmowanie stanowiska w przedmiocie: 1) środków odwoławczych dostępnych dla stron trzecich; 2) kwestii proceduralnych (np. określenie sytuacji prawnej); 3) okoliczności, w których sąd krajowy powinien zastosować środki tymczasowe lub 4) warunków ubiegania się o odszkodowanie w przypadku naruszenia prawa udzielania pomocy publicznej.

32 K. Saryusz-Wolska, M. Kośka, W poszukiwaniu utraconej skuteczności. Zasada natychmiastowego i skutecznego zwrotu pomocy państwa, [w:] B. Kurcz (red.), Prawo i ekonomia konkurencji. Wybrane zagadnienia, LEX Wolters Kluwer, Warszawa 2010, s. 392. 
W 2006 r. Komisja zleciła przeprowadzenie szczegółowej analizy egzekwowania przepisów o pomocy publicznej w różnych państwach członkowskich ${ }^{33}$. $\mathrm{Na}$ tej podstawie stwierdzono, że w latach 1999-2006 w państwach członkowskich znacznie zwiększyła się liczba wszczętych postępowań sądowych, dotyczących prawa udzielania pomocy publicznej. Pomimo faktu, że do niedawna rzeczywiste egzekwowanie przepisów w sądach krajowych miało ograniczony charakter, Komisja stoi na stanowisku, że wytaczane powództwa mogą przynieść istotne korzyści dla praktyki udzielania pomocy publicznej.

Komisja dąży do zintensyfikowania współpracy z narodowymi sądami państw członkowskich $w$ indywidualnych sprawach. Cel ten ma być osiągnięty poprzez zapewnienie praktycznych i prostych procedur kooperacji z krajowymi sędziami na wzór już istniejących mechanizmów w prawie antytrustowym ${ }^{34}$. Aby zrealizować powyższe zadanie, Komisja do niedawna pracowała nad przygotowaniem nowych przepisów w sprawie wykonalności prawa pomocy publicznej przez narodowe sądy ${ }^{35}$, które w kwietniu 2009 r. zastąpiły istniejące od 1995 r. obwieszczenie $^{36}$. W ramach tych działań opracowano pakiet informacyjny, zamieszczony na stronie internetowej Dyrekcji Generalnej ds. Konkurencji, oraz opublikowano broszurę $^{37}$ zawierającą najważniejsze wspólnotowe przepisy i wskazówki dla skutecznego egzekwowania prawa udzielania pomocy publicznej przez sądy państw członkowskich.

\section{POMOC NIEZGODNA Z PRAWEM}

Artykuł 108 ust. 3 TFUE zobowiązuje państwa członkowskie nie tylko do zgłaszania Komisji środków pomocy publicznej, lecz również do oczekiwania na ostateczny wynik postępowania prowadzonego przez Komisję, zanim nastąpi implementacja tych środków. Jeśli którykolwiek z powyższych warunków nie zostanie spełniony, udzieloną pomoc publiczną uznaje się za niezgodną z prawem ${ }^{38}$.

33 J. Derenne, T. Jestaedt, T. Ottervanger, Study on the enforcement of state aid law at national level, Brussels-Amsterdam, 15.03.2006.

34 Commission notice on the cooperation between the Commission and the courts of the EU Member States in the application of articles 81 and 82 EC, Official Journal C 101, 27.04.2004, s. 54 .

35 Commission notice on the enforcement of state aid law by national courts, Official Journal C 85, 09.04.2009, s. 1 .

36 Commission notice on cooperation between national courts and the Commission in the state aid field, Official Journal C 312, 23.11.1995, s. 8.

37 Enforcement of EU state aid law by national courts, European Commission, Brussels 2010.

38 P. Marquardt, Pomoc publiczna dla matych i średnich przedsiębiorców, Lexis Nexis, Warszawa 2007, s. 205. 
W okresie przypadającym na lata 2000-2010 Komisja wydała 910 decyzji, uznających pomoc publiczną za nielegalną. Niemal 22\% przypadków (197 spraw) dotyczących pomocy niezgodnej z prawem zakończyło się wydaniem decyzji negatywnych. W dalszych $2 \%$ spraw (19 przypadków) pomocy niekompatybilnej ze wspólnym rynkiem zapadły decyzje warunkowe. Ponadto aktualnie przed Komisją toczy się około 160 spraw będących przedmiotem postępowania wyjaśniającego na podstawie art. 108 ust. 3 TFUE. Sprawy te Komisja wszczęła z urzędu lub w wyniku złożonej skargi. Powyższe dane obejmują również sprawy z zakresu pomocy notyfikowanej przez państwa członkowskie, ale w których całkowite lub częściowe przyznanie określonych środków nastąpiło przed uzyskaniem stosownej aprobaty Komisji ${ }^{39}$.

Wartość wskaźnika interwencji Komisji (24\%) w udzielanie pomocy publicznej poprzez wydawanie negatywnych lub warunkowych decyzji dla części spraw nielegalnie implementowanej przez państwa członkowskie pomocy jest około dziesięć razy wyższa niż w przypadku spraw pomocy prawidłowo notyfikowanej $(2,7 \%)$. Udział spraw dotyczących pomocy niezgodnej z prawem i wymagających interwencji Komisji różni się w poszczególnych sektorach. Ponad połowa interwencji została podjęta w sektorze przemysłu i usług, a mniej niż jedna czwarta odnosiła się do sektora rolnictwa. Pozostała część interwencji była związana z sektorem transportu, górnictwem węgla kamiennego i rybołówstwem.

\section{ZWROT POMOCY PRZYZNANEJ BEZPRAWNIE}

Komisja podkreśliła w swoim planie działań w zakresie pomocy publicznej z 2005 r., że skuteczność i wiarygodność kontroli stosowania tego instrumentu zakłada odpowiednie egzekwowanie wydawanych przez nią decyzji. Komisja ogłosiła tym samym, że będzie dążyć do efektywnej i natychmiastowej wykonalności decyzji dotyczących zwrotu nielegalnej pomocy publicznej, zapewniając równość prawa wobec wszystkich jej beneficjentów ${ }^{40}$.

Ostatnie dane wskazują, że od 2005 r. nastąpił wyraźny postęp w wykonalności decyzji dotyczących zwrotu bezprawnie udzielanej pomocy publicznej. Do końca czerwca 2010 r. nierozstrzygnięte pozostawały 54 sprawy z tego zakresu. Dla porównania w roku 2004 liczba wszystkich toczących się spraw była prawie dwukrotnie większa (94 sprawy).

9 State aid scoreboard..., s. 63.

40 S. Paschalidou, Recovery of unlawful and incompatible state aid. Against all odds?, [w:] M. Krasnodębska-Tomkiel (red.), Zmiany w polityce konkurencji na przestrzeni ostatnich dwóch dekad, Urząd Ochrony Konkurencji i Konsumentów, Warszawa 2010, s. 367. 
Do połowy 2010 r. z 10 spraw o odzyskanie bezprawnie udzielonej pomocy 7 zostało zakończonych, a 3 wymagały ponownego rozpatrzenia. Największa liczba nierozstrzygniętych spraw dotyczyła Hiszpanii i Włoch (po 15, co stanowi $55 \%$ wszystkich spraw z tego zakresu we Wspólnocie). Na kolejnych miejscach pod względem liczby toczących się postępowań znalazły się Niemcy (7) i Francja (4). Warto podkreślić, że w 14 z 27 państw członkowskich nie było spraw nierozstrzygniętych ${ }^{41}$.

Tabela 1. Kierunki zmian w liczbie decyzji i wartość pomocy publicznej podlegająca zwrotowi w państwach UE-27 (stan na dzień 30.06.2010)

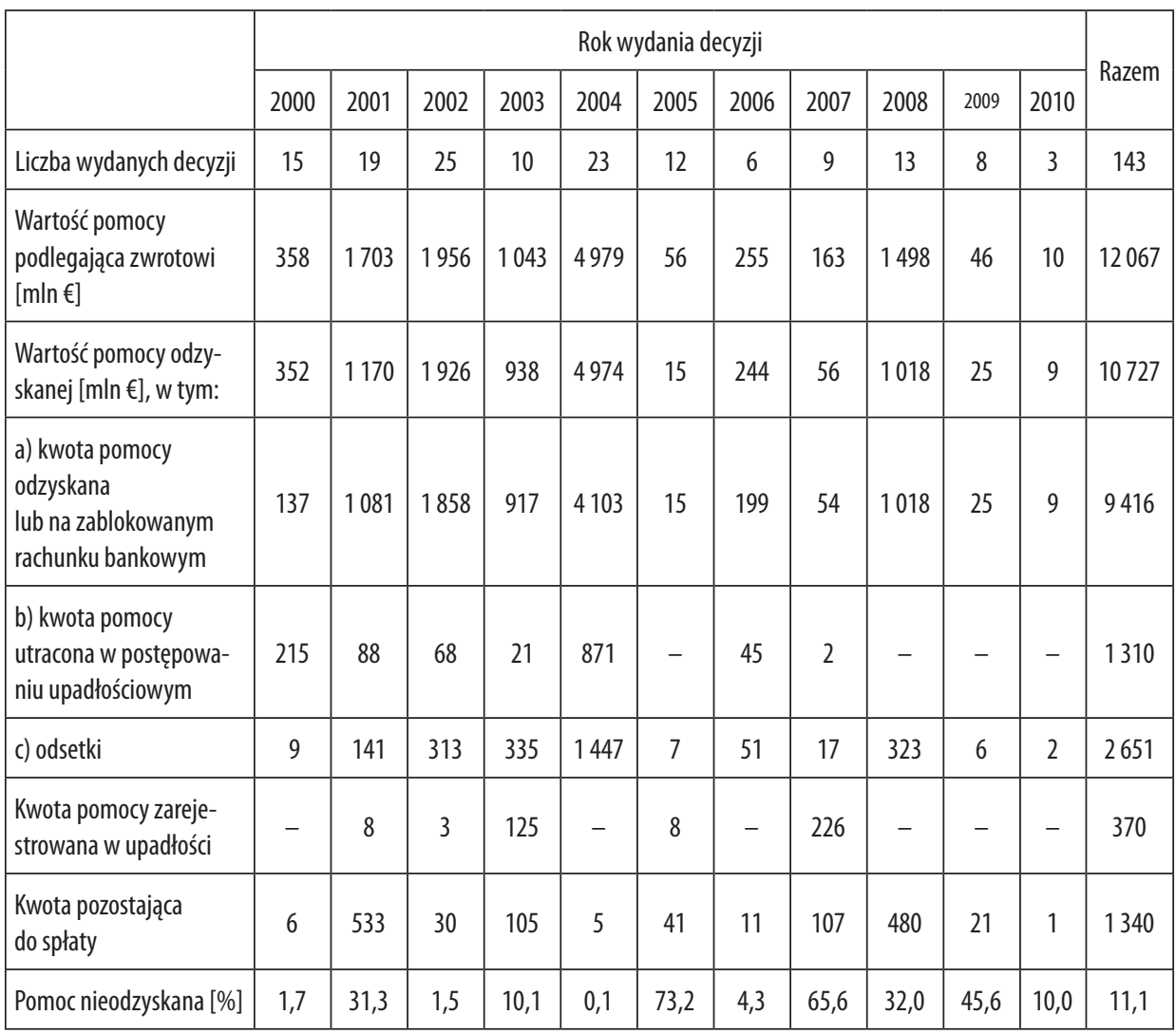

Źródło: opracowanie własne na podstawie danych z Dyrekcji Generalnej ds. Konkurencji.

Całkowita wartość pomocy publicznej podlegająca zwrotowi na podstawie 143 decyzji wydanych w latach 2000-2010 wyniosła prawie 12,1 mld euro (tab. 1). Z kwoty tej w ramach wszystkich decyzji wydanych do końca czerwca 2010 r. skutecznie odzyskano ponad 10,7 mld euro niezgodnej ze wspólnotowym

41 State aid scoreboard..., s. 64. 
rynkiem pomocy, jak również ponad 2,6 mld euro odsetek. Oprócz pomocy skutecznie odzyskanej, ponad 1,3 mld euro stanowiła bezprawnie przyznana pomoc publiczna, która została utracona w wyniku upadłości jej beneficjentów ${ }^{42}$. Oznacza to, że $88,9 \%$ całkowitej wartości pomocy publicznej niezgodnej z regułami jej dopuszczalności zostało skutecznie odzyskane ${ }^{43}$. Pozostałe $11,1 \%$ wartości pomocy stanowią niezakończone sprawy o odzyskanie przyznanych środków pieniężnych.

W okresie między 1999 r. a końcem czerwca 2010 r. Komisja wydała 14 decyzji $\mathrm{w}$ sprawie zwrotu nielegalnej pomocy $\mathrm{w}$ sektorze rolnictwa, z których 10 (o łącznej wartości 1,3 mld euro) wciąż nie zostało wykonanych. Niezakończone postępowania w tym zakresie wszczęto we Francji (3 sprawy), w Portugalii i Hiszpanii (po 2 sprawy w każdym z tych państw) oraz w Grecji, Niemczech i Włoszech (po 1 sprawie).

W sektorze rybołówstwa w badanym okresie Komisja wydała 7 decyzji nakazujących zwrot pomocy, z których 2 dotyczyły Francji (2004 r.), a 3 - Wielkiej Brytanii (2007 r.). Z kolei w 2010 r. Komisja skierowała 2 sprawy do ETS-u z powodu nieprzestrzegania przez państwo członkowskie postanowień TFUE. Całkowita wartość pomocy podlegającej zwrotowi we wszystkich wymienionych sprawach oscylowała w okolicach $100 \mathrm{mln}$ euro. Znaczną część tej pomocy zakwalifikowano jako środki, które nie zakłócają konkurencji w sposób sprzeczny z interesem Wspólnoty, wstrzymując się od podjęcia działań zmierzających do ich zwrotu.

W sektorze transportu wartość pomocy niezgodnej z prawem wynikająca z 7 decyzji Komisji nakazujących jej odzyskanie wyniosła 1,5 mld euro. W sektorze transportu powietrznego, poczynając od 2000 r., Komisja wydała decyzje negatywne związane $z$ udzielaniem pomocy publicznej przy świadczeniu usług lotniczych przewozów pasażerskich we Włoszech (przez Aitalia) i w Grecji (Olympic Airways Services). Postępowanie związane z odzyskaniem udzielonej pomocy w tych krajach spowodowało konieczność likwidacji poszczególnych przedsiębiorstw z powodu ich niewypłacalności.

W 2010 r. Sąd Pierwszej Instancji (dalej: SPI) uchylił decyzję Komisji, stwierdzając, że 131 mln euro przyznanych przez Grecję środków finansowych nie stanowiło pomocy.Jednocześnie SPI utrzymał w mocy inną decyzję Komisji, zgodnie

${ }^{42}$ W sprawach związanych z niewypłacalnością beneficjentów niezgodną ze wspólnym rynkiem pomocy roszczenie zwrotu pomocy jest zazwyczaj tylko częściowo zadowalające. $Z$ perspektywy konkurencji należy zauważyć, że zakłócenie konkurencji jest usunięte z chwilą likwidacji beneficjenta, pod warunkiem, że własność pozostałych po nim aktywów jest przenoszona na warunkach rynkowych.

43 Biorąc pod uwagę $370 \mathrm{mln}$ euro pomocy zarejestrowanej w upadłości, która stanowi 3\% pomocy podlegającej zwrotowi, można wysnuć wniosek, że skuteczność egzekucji bezprawnie przyznanych środków w badanym okresie wyniosła blisko $92 \%$. 
z którą niepłacenie przez greckiego przewoźnika podatków oraz składek z tytułu ubezpieczeń społecznych, oszacowane na łączną kwotę $354 \mathrm{mln}$ euro, uznano za bezprawną pomoc publiczną, która musi zostać zwrócona.

Zwrot pomocy publicznej niezgodnej ze wspólnotowymi regułami jej udzielania jest wciąż długotrwałym procesem. W ponad jednej trzeciej z 54 toczących się spraw decyzje nakazujące zwrot pomocy zostały wydane przed 2006 r. Największy wysiłek musi być zatem podjęty w przypadku odzyskania pomocy odnoszącej się do decyzji wydanych wiele lat temu.

Ważnym krokiem w tym kierunku było przyjęcie w 2007 r. zawiadomienia Komisji w sprawie skutecznego wykonywania decyzji nakazujących państwom członkowskim odzyskanie pomocy przyznanej bezprawnie, jako niezgodnej ze wspólnym rynkiem ${ }^{44}$. Zawiadomienie podkreśla, że zwiększenie skuteczności egzekwowania wydawanych decyzji zależy od odpowiedzialności państw członkowskich oraz ich współpracy z Komisją. Jednocześnie odwołuje się ono do zasad stosowanych przy odzyskiwaniu pomocy, które zostały potwierdzone przez sądy państw członkowskich, oraz określa rzeczywistą rolę Komisji i państw członkowskich w prowadzonych w tym zakresie procedurach.

Komisja monitoruje bardzo dokładnie egzekwowanie decyzji dotyczących zwrotu bezprawnie przyznanej pomocy w poszczególnych państwach członkowskich. W przypadku, kiedy państwo członkowskie nie podejmie wszystkich możliwych działań w celu wykonania wydanych przez nią decyzji, Komisja konsekwentnie wszczyna postępowanie $\mathrm{w}$ sprawie naruszenia zobowiązań przeciwko temu państwu członkowskiemu w związku z artykułami 108(2), 258 i 259 TFUE.

\section{MONITORING EXPOST}

W celu zapewnienia kontynuacji w budowie nowego systemu kontroli pomocy publicznej, w którym wzrastająca liczba środków nie jest już przedmiotem obowiązkowej notyfikacji, Komisja przyspieszyła monitoring ex post tych środków. Rozwój w tym zakresie zasadniczo jest rozpatrywany w świetle faktu, że państwa członkowskie coraz częściej realizują zadania polityki gospodarczej za pośrednictwem wcześniej zatwierdzonych programów i środków pomocy wynikających z przepisów o wyłączeniach grupowych.

W związku z powyższym Dyrekcja Generalna ds. Konkurencji rozpoczęła w 2006 r. próbny monitoring obejmujący swym zasięgiem programy i środki

44 Notice from the Commission: Towards an effective implementation of Commission decisions ordering Member States to recover unlawful and incompatible state aid, Official Journal C 272/05, 15.11.2007, s. 1-14. 
pomocy podlegające wyłączeniom grupowym. Na podstawie doświadczeń zebranych w tym pierwszym pilotażowym projekcie podobne czynności zostały podjęte w latach 2007-2010. Opierając się na tych doświadczeniach, Dyrekcja Generalna ds. Konkurencji dokonała oceny: 1) określonych środków finansowych implementowanych w szczególności na podstawie wyłączeń grupowych dla małych i średnich przedsiębiorstw, w tym: pomocy na zatrudnienie i szkolenia oraz pomocy regionalnej; 2) zasad ramowych dotyczacych pomocy publicznej na działalność badawczą, rozwojową i innowacyjną; 3) wytycznych Komisji dotyczących pomocy publicznej na ochronę środowiska; 4) wytycznych Wspólnoty w sprawie pomocy publicznej na ratowanie i restrukturyzację zagrożonych przedsiębiorstw.

Przeprowadzony monitoring miał miejsce zarówno na poziomie danego programu, jak i na poziomie ważnych indywidualnych decyzji wdrażających ten program. Dyrekcja generalna ds. Konkurencji zajęła się również środkami pomocy publicznej, przyjętymi przez wszystkie 27 państw członkowskich, zapewniając tym samym ich geograficznie zrównoważoną ocenę.

Analiza wyników dotyczących dwóch pierwszych doświadczeń wskazuje, że część istniejącego systemu pomocy publicznej, pozwalającego zarówno zatwierdzić programy pomocy, jak i implementować w państwach członkowskich środki wynikające $z$ przepisów o wyłączeniach grupowych, funkcjonuje w zadowalający sposób. W mniejszym stopniu zidentyfikowane zostały poważne problemy lub kwestie proceduralne, takie jak: transparentność, sprawozdawczość czy szybkość i jakość udzielanych przez państwa członkowskie odpowiedzi. Sprawy, w których odpowiednie rozwiązanie nie zostało jeszcze znalezione, są obecnie przedmiotem prowadzonych badań. Ostatecznie należy zaznaczyć, że wszystkie państwa członkowskie współpracują z Komisją, aczkolwiek wiele składanych przez nie informacji dociera do Komisji ze znacznym opóźnieniem.

\section{ZAKOŃCZENIE}

W ostatnich latach Komisja prowadzi konsekwentne działania wymierzone przeciwko bezprawnie przyznawanej pomocy publicznej. Rewindykacja pomocy niezgodnej z rynkiem wewnętrznym nie jest karą, lecz logiczną konsekwencją zakłócenia konkurencji i stanowi działanie współmierne do celów Unii Europejskiej. Przywrócenie warunków rynkowych następuje z chwilą zwrotu przez beneficjenta przyznanej bezprawnie i niezgodnej z europejskim prawem konkurencji pomocy, wskutek czego traci on przewagę uzyskaną na rynku względem swoich konkurentów.

Sądy państw członkowskich odgrywają istotną rolę w postępowaniach związanych $\mathrm{z}$ naruszeniem prawa pomocy publicznej w Unii Europejskiej. Niemniej 
rola ta jest nieco ograniczona, ponieważ sądy krajowe nie mogą orzekać o zgodności pomocy publicznej z art. 107 ust. 2 i 3 TFUE, a jedynie dokonują interpretacji pojęcia pomocy oraz oceniają, czy państwa członkowskie wypełniają swoje obowiązki w tym zakresie. $Z$ drugiej strony sądy krajowe, chroniąc prawa konkurentów, uzupełniają system kontroli prawa pomocy publicznej, przyczyniając się w znacznym stopniu do powszechnego przestrzegania zasady notyfikacji nowej pomocy. Dodatkowo należy podkreślić, że to właśnie sądy krajowe w dalszym postępowaniu stają się gwarantem usunięcia zakłócenia konkurencji.

Konieczność rozstrzygania złożonych kwestii z zakresu prawa konkurencji w kontekście dopuszczalności pomocy publicznej, pociągająca za sobą rozmaite pytania o stosunek i wykładnię prawa Unii Europejskiej, spowodowała, że interpretację prawa i legalności aktów wydawanych przez unijne instytucje pozostawiono wyłącznie ETS. Chociaż orzeczenia ETS wywierają wpływ na działania sądów krajowych, to nie ma on jednak jurysdykcji do orzekania w konkretnych sprawach oraz nie może stwierdzać, czy krajowe przepisy prawne są legalne. Niemniej orzeczenia ETS, jako prawnie wiążące i ostateczne, muszą być uwzględniane przez sądy państw członkowskich, co powoduje, że ETS odgrywa również bardzo ważną rolę w rozwoju unijnego prawa pomocy publicznej.

Zachowanie spójności systemu kontroli i egzekwowania prawa pomocy publicznej pociąga za sobą konieczność bezzwłocznego i skutecznego wykonywania decyzji Komisji. Z uwagi na przewlekłość postępowań w sprawach dotyczących pomocy publicznej państwa członkowskie powinny zwrócić szczególną uwagę na usprawnienie procedur w tym zakresie oraz ściślej współpracować z Komisją. Rezultatem tych skoordynowanych działań będzie lepsza dyscyplina w udzielaniu pomocy publicznej w Unii Europejskiej.

\section{BIBLIOGRAFIA}

Bokajło W., Pacześniak A. (red.), Równość w Unii Europejskiej-teoria i praktyka, Wrocław 2008.

Brodecki Z. (red.), Konkurencja, Lexis Nexis, Warszawa 2004.

Ćwikliński H. (red.), Polityka gospodarcza, Gdańsk 2003.

Derenne J., Jestaedt T., Ottervanger T., Study on the enforcement of state aid law at national level, Brussels-Amsterdam, 15.03.2006.

Dudzik S., Pomoc państwa dla przedsiębiorstw publicznych w prawie Wspólnoty Europejskiej. Między neutralnościq a zaangażowaniem, Kraków 2002.

Enforcement of EU state aid law by national courts, European Commission, Brussels 2010. Jalowietzki D., Jaros K., Klaue S., Vennemann H. P., Wspólnotowe reguty prawa konkurencji $i$ ich znaczenie dla polskich sędziów, Urząd Ochrony Konkurencji i Konsumentów, Warszawa 2007. 
Jankowska A., Marek M., Dopuszczalnośé pomocy publicznej. Uregulowania wspólnotowe i krajowe, C. H. Beck, Warszawa 2009.

Kąkol M., Pomoc państwowa w polityce konkurencji w Unii Europejskiej, Lublin 2007.

Klamut M., Polityka strukturalna, [w:] B. Winiarski (red.), Polityka gospodarcza, Warszawa 2006.

Korbutowicz T., Polityka konkurencji Wspólnoty Europejskiej i Unii Europejskiej w latach 1962-1997, Oficyna Ekonomiczna, Kraków 2004.

Kośka M., Co cesarskie cesarzowi. Zwrot pomocy państwa, [w:] B. Kurcz (red.), Pomoc pañstwa. Wybrane zagadnienia, C. H. Beck, Warszawa 2009.

Majewska-Jurczyk B., Dominacja w polityce konkurencji Unii Europejskiej, Wrocław 1998.

Marquardt P., Pomoc publiczna dla matych i średnich przedsiębiorców, Lexis Nexis, Warszawa 2007.

Nykiel-Mateo A., Pomoc państwa a ogólne śodki interwencji w europejskim prawie wspólnotowym, Oficyna Wolters Kluwer, Warszawa 2009.

Paschalidou S., Recovery of unlawful and incompatible state aid. Against all odds?, [w:] M. Krasnodębska-Tomkiel (red.), Zmiany w polityce konkurencji na przestrzeni ostatnich dwóch dekad, Urząd Ochrony Konkurencji i Konsumentów, Warszawa 2010.

Podlasiak Z., Pomoc publiczna a efektywnośc wykorzystania zasobów, [w:] A. Fornalczyk (red.), Pomoc publiczna dla przedsiębiorstw w Unii Europejskiej $i$ w Polsce, Warszawa 1998.

Postuła I., Werner A., Pomoc publiczna, Warszawa 2006.

Przybyciński T., Konkurencja $i$ tad rynkowy - przyczynek do teorii i polityki konkurencji, Warszawa 2005.

Rutkiewicz K., Pomoc publiczna w polityce konkurencji Unii Europejskiej a kryzys finansowy, [w:] G. Wrzeszcz-Kamińska (red.), Zawodność państwa. Zawodnośc rynku, Wrocław 2010.

Saryusz-Wolska K., Kośka M., W poszukiwaniu utraconej skuteczności. Zasada natychmiastowego i skutecznego zwrotu pomocy państwa, [w:] B. Kurcz (red.), Prawo i ekonomia konkurencji. Wybrane zagadnienia, LEX Wolters Kluwer, Warszawa 2010.

Skoczny T., Zakaz antykonkurencyjnej pomocy państwa, [w:] J. Barcz (red.), Prawo Unii Europejskiej, Warszawa 2004.

State Aid Action Plan. Less and better targeted state aid: A roadmap for state aid reform 2005-2009, Commission of the European Communities, Brussels 07.06.2005.

State aid scoreboard. Report on state aid granted by the EU Member States. Autumn 2010 update, European Commission, Brussels 2010.

\section{ŹRÓDŁA PRAWA}

Commission notice on cooperation between national courts and the Commission in the state aid field, Official Journal C 312, 23.11.1995.

Commission notice on the cooperation between the Commission and the courts of the EU Member States in the application of articles 81 and 82 EC, Official Journal C 101, 27.04.2004.

Commission notice on the enforcement of state aid law by national courts, Official Journal C 85, 09.04.2009. 
Komunikat Komisji w sprawie elementów pomocy państwa w sprzedaży gruntów i budynków przez władze publiczne, Dz. Urz. C 209 z 10.07.1997.

Komunikat Komisji do państw członkowskich zmieniający zgodnie z art. 93 ust. 1 Traktatu WE komunikat dotyczący stosowania art. 92 i 93 Traktatu do krótkoterminowych ubezpieczeń kredytów eksportowych, Dz. Urz. C 325 z 22.12.2005.

Komunikat Komisji, Kodeks najlepszych praktyk dotyczących przebiegu postępowania w zakresie kontroli państwa, Dz. Urz. C 136, 16.06.2009.

Notice from the Commission: Towards an effective implementation of Commission decisions ordering Member States to recover unlawful and incompatible state aid, Official Journal C 272/05, 15.11.2007.

Obwieszczenie Komisji w sprawie stosowania reguł pomocy publicznej do środków związanych z bezpośrednim opodatkowaniem działalności gospodarczej, Dz. Urz. C 384 z 10.12.1998.

Obwieszczenie Komisji w sprawie zastosowania art. 87 i 88 Traktatu WE do pomocy państwa w formie gwarancji, Dz. Urz. C 155 z 20.06.2008.

Rozporządzenie Komisji (WE) nr 800/2008 z 06.08.2008 uznające niektóre rodzaje pomocy za zgodne ze wspólnym rynkiem w zastosowaniu art. 87 i 88 Traktatu, Dz. Urz. L 214, 09.08.2008.

Rozporządzenie Rady (WE) nr 659/1999 z 22.03.1999 r. ustanawiające szczegółowe zasady stosowania art. 93 TWE, Dz. Urz. L 83, 27.03.1999.

Traktat o funkcjonowaniu Unii Europejskiej z 09.05.2008 r., Dz. Urz. UE C 115/2008.

Wspólnotowe zasady ramowe dotyczące pomocy państwa na działalność badawczą, rozwojową i innowacyjną, Dz. Urz. C 323 z 30.12.2006.

Wytyczne wspólnotowe $\mathrm{w}$ sprawie pomocy państwa na wspieranie inwestycji kapitału podwyższonego ryzyka w małych i średnich przedsiębiorstwach, Dz. Urz. C 194 z 18.8.2006.

Zawiadomienie Komisji w sprawie uproszczonej procedury rozpatrywania niektórych rodzajów pomocy państwa, Dz. Urz. C 136, 16.06.2009.

Orzecznictwo Europejskiego Trybunału Sprawiedliwości i Sądu Pierwszej Instancji

Sprawa 78/76, Steinike \& Weinlig v Federal Republic of Germany, Judgment of the Court of 22.03.1977, European Court reports, 1977.

Sprawa 730/79, Philip Morris Holland BV v Commission of the European Communities, Judgment of the Court of 17.09.1980, European Court reports, 1980.

Sprawa C-142/87, Kingdom of Belgium v Commission of the European Communities, Judgment of the Court of 21.03.1990, European Court reports, 1990.

Sprawa C-354/90, Fédération Nationale du Commerce Extérieur des Produits Alimentaires and Syndicat National des Négociants et Transformateurs de Saumon v French Republic, Judgment of the Court of 21.11.1991, European Court reports, 1991.

Sprawy połączone C-278/92, C-279/92 i C-280/92, Kingdom of Spain v Commission of the European Communities, Judgment of the Court of 14.09.1994, European Court reports, 1994. 
Sprawa C-39/94, Syndicat français de l'Express international (SFEI) and others v La Poste and others, Judgment of the Court of 11.07.1996, European Court reports, 1996.

Sprawa C-342/96, Kingdom of Spain v Commission of the European Communities. Application of the statutory interest rate to agreements for the repayment of wages and the payment of debts in respect of social security contributions, Judgment of the Court of 29.04.1999, Official Journal C 204, 17.07.1999.

Sprawa C-280/00, Altmark Trans GmbH and Regierungspräsidium Magdeburg v Nahverkehrsgesellschaft Altmark $\mathrm{GmbH}$, and Oberbundesanwalt beim Bundesverwaltungsgericht, Judgment of the Court of 24.07.2003, European Court reports, 2003.

Sprawa C-368/04, Transalpine Ölleitung in Österreich GmbH, Planai-HochwurzenBahnen GmbH, Gerlitzen-Kanzelbahn-Touristik GmbH \& Co KG v Finanzlandesdirektion für Tirol, Finanzlandesdirektion für Steiermark, Finanzlandesdirektion für Kärnten, Judgment of the Court of 5.10.2006, European Court reports, 2006.

\section{STRESZCZENIE}

W artykule autor odnosi się do problematyki kontroli i egzekwowania prawa pomocy publicznej w Unii Europejskiej w latach 2000-2010. Przedstawiono system kontroli pomocy publicznej w świetle nowych reguł i procedur jej dopuszczalności. Zaprezentowano kompetencje Komisji Europejskiej i rolę sądów państw członkowskich w kształtowaniu polityki udzielania pomocy publicznej. Artykuł zawiera dane empiryczne przedstawiające kierunki zmian w wartości i strukturze udzielania pomocy publicznej w Unii Europejskiej. Analizie poddano praktykę wydawanych przez Komisję Europejską decyzji, uznających pomoc publiczną za niezgodną z europejskim prawem konkurencji oraz będących przedmiotem prowadzonego postępowania wyjaśniającego. W tym kontekście zaprezentowano informacje dotyczące liczby spraw i wartości pomocy publicznej podlegającej zwrotowi w poszczególnych państwach członkowskich oraz odnoszące się do interwencji podjętych w różnych sektorach gospodarki Wspólnoty.

\section{THE SYSTEM OF CONTROL AND ENFORCEMENT OF STATE AID LAW IN THE EUROPEAN UNION - THE EUROPEAN COMMISSION'S POWERS AND ITS COOPERATION WITH THE MEMBER STATES' COURTS IN THE YEARS 2000-2010}

\section{SUMMARY}

In this article the author refers to issues relating to the system of control and enforcement of state aid law in the European Union in the years 2000-2010. It presented the architecture of the state aid control system in the light of new rules and procedures for its admissibility. The analysis concerned the European Commission's powers and the role of the Member States' courts in state aid policy-making. The article contains empirical data 
showing the direction of changes in the value and structure of state aid in the European Union. The study involved the practice issued by the European Commission decisions declaring state aid as incompatible with European competition law and these are the subject of the investigation procedure. In this context information is presented on the number of cases and the value of state aid to be recovered in the Member States, referring to the interventions undertaken in various sectors of the European Community. 
